\title{
MECHANISM OF ACCOUNTING EMOTIONS \\ IN LEGAL REGULATION OF PRIVATE RELATIONS
}

Ustymenko O. A.

\section{INTRODUCTION}

Virtually the entire history of mankind illustrates how certain emotions influence social communities. It was emotions that led to breakthroughs in human development (there are numerous examples of scientific discoveries made in the state of an emotional uplift) or to the most devastating events that proved to be obstacles for further progress (in this regard both local and global wars are striking examples). Emotions are also the driving force that makes average people act in a certain way. And the activity caused by emotions can be found almost in any area, both private, e.g. buying, and public. Emotioncaused actions can be of different connotation, either extremely negative for the society, for example, a murder caused by jealousy, or positive, for instance financial support of orphanages. It is also worth noting that people acting in a certain way, when influenced by emotions, almost never pay any attention to how these emotions are appraised by the state and law or what consequences they have for themselves and the society. At the same time, taking into account quite a wide scope of results, which emotion-caused actions cause for the society, the science has specific tasks that must be investigated to avoid negative effects for the society or, if impossible, to take them into consideration and reduce the consequences. In our opinion, presently, with regard to the development of our society, the reflection of emotions in law and improvement of the regulation of emotion-caused actions is an urgent problem. So, we consider it to be our task to clarify the essence and nature of emotions and determine, to what extent they can be taken into account while creating new regulations.

Human behaviour is studied by different branches of science. At the same time human behaviour as a direct object and subject matter of investigation is used in biology, sociology, psychology, economics and legal studies. Representatives of these sciences investigate emotion-caused actions from the perspective of their specific subject matter: biology - interaction of biological creatures under the influence of emotions; sociology interaction of social players and institutions under the influence of emotions; psychology - individual and collective inner factors of interaction under the influence of emotions; economics - carrying out of economic activity under the influence of emotions; jurisprudence - reaction of the state to emotion- 
caused actions of its citizens. Whereas biology, sociology and psychology have been carrying out their investigation for a long time, representatives of economics and, since the latest decades, legal studies have only just begun showing interest to this issue. For instance, the theory of behavioural economics is getting more popular in economic studies ${ }^{1}$. Jurisprudence has got interested in emotions and law lately. In particular, in 1999 "The Passions of Law" by Susanne Bandes ${ }^{2}$ was published, then the materials of a symposium on law, psychology and emotions ${ }^{3}$ came into being and a book "Frontiers of Love" by outstanding modern researcher Richard Posner was published, which includes a chapter on emotions and law. Almost 15 years later the XXVII World Congress on Philosophy of Law and Social Philosophy was held, whose topic was "Law, Mind and Emotions".

Speaking about the state of research on emotions in Ukrainian legal studies, unfortunately this issue was neglected for a long time. In 2015 "Philosophy of Law and General Theory of Law" journal organized a scientific discussion on problems of the rational and emotional in law". In addition, the Great Ukrainian Judicial Encyclopedia, whose publication was launched by the leading research institutions of Ukraine, includes "Legal Emotions" in its second volume, and this can also be considered a contribution of a kind to the establishment of Ukrainian judicial doctrine.

\section{The emotions and legal psychology}

In what follows we are going to use the achievements of predecessors, the basic approach being the position of Richard Posner since it is the most grounded. At the same time, unlike the tasks he set for himself in his work ${ }^{8}$, we will try to answer the question, what emotions must be fixed in law-making instruments, if possible, and what mechanisms for this fixation are available.

\footnotetext{
1 Таллер Р. Поведінкова економіка / перекл. 3 англ. С. Крикуненко. Київ : Наш формат, 2018. $464 \mathrm{c}$.

2 The Passions of Law / ed. S.F. Bandes. New York : University Press, New York and London, 1999. 236 p.

3 Symposium on Law, Psychology, and the Emotions. Chicago-Kent Law Review. 2000. Vol. 741.

4 Posner, R.A. Frontiers of Legal Theory. Published by arrangement with Harvard University Press. 225 p.

5 URL: https://ivronlineblog.wordpress.com/2014/09/04/httpivr2015-org/

6 Вест Р. Правові емоції. Філософія права і загальна теорія права. 2015. № 1-2. URL: https://pravoua.com.ua/ua/store/philosophy/phil-law_1-2_15/.

7 Велика українська юридична енциклопедія : у 20 т., Т. 2. Харків : Право, 2017. С. 255-258.

8 Posner, R.A. Frontiers of Legal Theory. Published by arrangement with Harvard University Press. P. 225-226
} 
In our opinion, the studying of emotions and law should begin with clarification of the basic categories, including "relations", "legal relations" and "emotions". They will be used as the basis for us in our aiming to answer the specified questions.

The notion "relations" is used by different sciences, what results in a wide range of its interpretation. At the same time, by applying an interactive approach, relations are most often explained as real mutual relationship in the social space of people with certain conscience and will, who pursue a certain objective. Special attention must be paid to the fact that the mutual relations in practice are always expressed in actions, gestures of participants, etc. The reason for the relation to appear is an aspiration of one or all participants to meet their own needs or interests.

Historical and anthropological research shows that it was the existence of relations among members of different societies that served as the catalyst that caused the necessity to regulate these relations. At the initial stages of the development of mankind this regulation was carried out by respected representatives such as heads of families, tribal chiefs, council of chiefs and others. Later the state undertook the regulation function. The basic and most efficient instrument to regulate social relations is law as freedom of an individual that was granted and limited by commonly binding norms accepted in the form of the established order and whose violation can lead to the use of certain means of enforcement. Law is known to perform two basic functions: regulatory and protective. Consequently, the relations, within which these two functions are executed in practice, are to be considered legal. Thus, legal relations are social relationships regulated by provisions of law that are established by law-making instruments adopted according to the procedure established by the law to realize legal rights and interests of the participants.

Taking into consideration the above, we can legitimately say that law is a social regulator that is the most sensible from the point of view of the empirical reality. In this regard we should agree with the statement of Richard Posner, who stated that law is considered to be "a bastion" of mind and a complete opposite to emotions ${ }^{9}$. Law is that very instrument that, in the opinion of researchers, neutralizes emotions for the sake of ensuring justice.

At the same time, if we study relations in their practical execution, we understand that their overwhelming majority is coloured with certain emotions that are manifested both in a usual conversation and when

\footnotetext{
9 Posner, R.A. Frontiers of Legal Theory. Published by arrangement with Harvard University Press. P. 225-226.
} 
performing some actions. So what are the emotions that can sometimes exercise dramatic influence on our behaviour?

It is thought that investigation of emotions and their accounting within legal regulation of social relations are impossible without understanding of their essence and nature. For us, representatives of legal studies, it is quite difficult to realize the essence and nature of emotions because it requires taking into consideration the discoveries of not only sociology but also biology, psychology, philosophy and medicine.

Given the fact that the authors are not competent enough in the mentioned branches of science, we are going to refer to the research carried out by acknowledged researchers from all over the world, who studied emotions and emotional aspect.

Modern research proves ${ }^{10}$ that emotions play a crucial role in the evolution of conscience of an individual. They are motivational and informational due to the presence of a sensual and empirical component. Practice shows that emotions help organize and motivate actions that are of key importance for an adaptive response to direct challenges for survival or well-being.

It is also worth noting that emotions on the biological level of a person cannot be distorted. They are always present in the conscious brain though not always expressed or articulated. In this aspect we should agree with Edelman and Tononi ${ }^{11}$ who say that emotions are of fundamental importance both for the beginning and the conscious thought of appetite. Thus, conscience looks more like effects of emotions than their originating sources.

The latest research also proves that discrete emotional experiences develop in the course of individual development of a human body, long before children master their language to share their condition with people around. Moreover, the research by Langer ${ }^{12}$ shows that even grown-ups have great difficulties when identifying and describing the exact state of their emotions. This is proven by the fact that emotions are a part of human conscience, whose emergence is the least controllable. People can analyze them and to some extent be aware of them but are unable of producing them. Emotions can be activated by perceptive, appraising and non-cognitive processes, but their influence cannot produce these emotions.

10 Izard, Carroll E. Emotion Theory and Research: Highlights, Unanswered Questions, and Emerging Issues. Annual Review of Psychology. Vol. 60. P. 1-25.

11 Edelman G.M, Tononi G. A Universe of Consciousness: How Matter Becomes Imagination. New York : Basic Books, 2000. 274 pp.

12 Langer SK. 1967/1982. Mind: An Essay on Human Feeling. Baltimore, MD : Johns Hopkins Univ. Press. Vol. 1. P. 101. 
In this aspect we are inclined to support the opinion of Carrol Izard who states that experiencing of emotions is a stage of neurobiological activity that is independent from the body because they, as the research by Bjorn Marker shows ${ }^{13}$, are felt and expressed even in children without cerebral cortex. In other words, appearance of emotions does not require any skills, habits or high level of nervous system activity.

This interpretation of emotions allows saying that in social aspect by their nature they are similar to instincts that cannot be produced consciously. The main psychological aspects of emotions are motivation and information. Motivational, generating and informative functions of feelings enable a person to facilitate and organize her reactions that in future can become the majority of impulses for adaptive actions in life, what results in further individual psychological development of a personality.

With regard to everything mentioned above we can state that emotions as a neurobiological activity caused by certain factors are mostly uncontrollable on the part of the person to produce them. Emotional states can depend on the activity of the person, her health condition or temperament. In the context of our research a justified question can be asked: how can emotions be regulated with the help of legal regulation, if a person is unable of controlling them?

The given conclusion concerns the biological and psychical side of emotions. At the same time they have a social side too, which we must also pay attention to.

\section{The emotions in the social regulation of relationships}

Since the middle of the previous century the biggest step in the development of legal research has been the increasing number of interdisciplinary legal researches by means of using the results of social and humanitarian investigations to study law. This tendency of the research was justified by the need to do the law less formalized, more practical and adjusted to the requirements of the society. The leader of the trend was Richard A. Posner (Posner R.A., 1979), who distinguished five directions to develop interdisciplinary researches: history, economics, psychology, epistemology of law and empirical study of law. The author has all the good reasons to state that these approaches provide for mutual penetration and profound investigation of the theory of law from different points of view and can explain such diverse socio-legal phenomena as economics

13 Marker B. Consciousness without a cerebral cortex: a challenge for neuroscience and medicine. Behavioral and Brain Sciences. 2007. Vol. 30, Issue. P. 63-81 
of the freedom of speech, possession right, psychology of decision-making, role of emotions in law and the use of court judgment analysis with view of appraising the professional level of judges and professors of law.

Richard A. Posner was right as nowadays the research of the role and significance of emotions in social relations, including legal ones, is becoming more intense in various directions, starting with the investigation of general theoretical issues (Elster J., 1989, 2007, 2011 ; Holland J., 2007 ; Bericat E., 2015) up to the research of the influence of emotions in specific legal relations, namely emotions in politics and managements (D. Moïsi, 2009), causing damage (Weenink D., 2014), ensuring of stable law and order in the country (Louwanda Evans, Joe R. Feagin, 2015), influence of emotions on the behaviour of public figures when making legally significant decisions (Bergman Blix S., Wettergren A., 2016), etc.

D. Weenink published the results of their analysis of over 150 legal cases, the subject matter thereof was the research of emotional dynamics, emotional balance when causing harm with extreme violence among the youth. Louwanda Evans and Joe R. Feagin investigated the influence of emotions on the policemen while performing their duty, including the influence of emotions on the eligibility of their use of violence. The investigation development in this direction proves the good perspectives and the necessity to include emotions and emotional state in the research as one of subjective factors influencing behaviour and shaping of the norms that are to effect and correct the behaviour of legal relation agents both in private and public field of law and legislation.

The researchers argue ${ }^{14}$ that from social point of view emotions are the process of impulse regulation of behavior based on the reflection of positive or negative factors on human body. The emotional reactions of an individual in the society are connected tightly with sense perceptive, cognitive and movement systems. In other words, this is a peculiar class of psychological states in the shape of the direct experiencing of the positive or negative, pleasant or unpleasant, person's attitude towards the world and the surroundings as well as the processes resulting from her practical activity with view of meeting the pressing requirements. Every society has its own rules as to which emotions are acceptable and in what way they are to be expressed. If an individual violates the rules of social reality of the society, in which he or she lives, this can lead to punishment, whose most wide-spread type is social isolation.

14 Крюкова Е.А. Управление эмоциями как фактор эффективного менеджмента. Российское предпринимательство. 2015. Т. 16. № 12. С. 1937-1948 
In some societies (states) lack of emotions is also perceived as a ground to establish social relations. Depending on emotions, their presence or absence a social interaction can be launched or terminated, it can get positive or negative connotation and finally it can develop to positive or negative legal relations. In international diplomacy this can be a reason to start a war (casus belli).

Reserved behaviour is required in the majority of modern societies regardless of the level of their civilization development. Members of the royalty are brought up with the demand not to express any sharp, extreme emotions. This phenomenon can be culturally preconditioned. Lack of self-control in those possessing the powers of authority is considered equivalent to their inability to make wise, well-balanced and, consequently, fair decisions that are for the better of the country and society.

An example of emotionality is expressing of personal opinion on certain taboo issues that are not prohibited officially, for which read they are not regulated by legislative prohibitions, but royal social norms (the norms of ethics) require refraining from them. For instance, during their official visit to Ireland Prince Harry and Meghan Markle expressed their point of view concerning the burning issue of abortions. Though it is not forbidden officially to speak on critical problems, Queen Elizabeth II does not approve of such acts because they always have as a result that a certain group of people are not satisfied with the position of the royal family and the latter loses the support of a part of the society.

\section{The emotions in private legal regulation}

Virtually in every state the limits of emotion expression and their appraisal are established by the system of law and order functioning on its territory. In other words, we can say that the practice to interpret emotions as a neurobiological activity causing the uncontrollable behaviour of a person does exist but it is quite limited. The basic method is a simple assertion that emotions are present in humans as biological creatures and can influence the behaviour of people or its appraisal on the part of the state.

The analysis of law enforcement in practice and creation of regulations shows that at the modern stage of our society's development it is not enough to assert the presence of emotions in parties of legal relations as biological creatures to regulate the law in an effective way. Modern society that aspires to develop as a fair one requires more prudent and foreseeable approaches to legal regulation of emotions and emotional states of people. 
The law aspires to equality and justice in its regulation by pushing aside everything biased, ambiguous, what means individual or stands for individualism. But at the same time the law cannot be just, especially regarding the principle of the supremacy of the law, if it fails to take into account such a subjective factor as emotions and emotional states. Moreover, the civil legislation has established such emotions in the laws currently in effect as the grounds for the legal regulation of private relations.

Some examples of emotions and emotional states established by the legislation as the grounds for the appearance of private legal relations can be found in the Family Code of Ukraine, where it is stated that «... relations in a family are regulated by this Code for the purpose of creating family relations... on the feelings of mutual love and respect...» (Article 1), «Wife and husband must make sure together that their relations with each other and with other family members are built on the feelings of mutual love, respect, friendship...» (Article 55); «Parents must bring their child up with respect to the rights and freedoms of other people, love for their family, people and Motherland...» (Article 150).

In a similar fashion, in inheritance relations the legislator has made it possible for inheritance relations to appear because of the presence of positive emotions or feelings even if a person «... knew about an attempt upon her life and still appointed the person in question to be her lawful heir» (passage 2, part 1, Article 1224 of the Civil Code of Ukraine). But as proven by the analysis of court practice, courts never refer to the mentioned articles, when issuing their judgment in relevant cases. It means that not all factors are taken into account when taking decisions by courts and, consequently, it can be doubted if these courts stick to such principles as justice and the supremacy of the law.

In our opinion, an instrument that enables gaining prudence and predictability of legal regulation is the development of judicial structures that take into consideration the presence of emotions in the parties of legal relations. In the history of judicial thought judicial structures were studied by representatives of analytical jurisprudence (H. Kelsen, J. Austin, H.L.A. Hart). In their works all of them tried to find fundamental particles of law but did not study the question of their interconnection or the result thereof. One of the first to pay attention to the presence of certain particles in law that can be combined in legal instruments was R. von Jhering ${ }^{15}$. In his works the author makes the following conclusion: for the law to

15 Иеринг Р. Избранные труды в 2-х томах. Санкт Петербург : Юридический центр пресс, 2006. T. 2. C. $326-329$. 
become complete and genuine and for jurisprudence to become genuine jurisprudence in the true sense of the word, they should refuse from the idea of a legal norm as a fundamental element of law and a carrier of legal meaning. Jhering thinks that it is possible to overcome the limits of natural, "lower" state of law only if jurisprudence begins to consider not the legal norm as a unit of law but a principally new entity, i.e. judicial structure that is a historical alternative for the legal norm ${ }^{16}$. In this aspect the author makes a crucial conclusion: a judicial structure is a plastic instrument of jurisprudence, whose subject matter and aim is a judicial body ${ }^{17}$.

At the modern stage of development of legal studies the issue of judicial structures has been developed most substantially in the works by S.S. Alekseyev ${ }^{18}$. The research conducted by the author enabled him to come to the following conclusion: judicial structures are a "backbone, an infrastructure, a model that are to ensure the best social result" and the maturity of judicial structures is a proof that the legislation is perfect, it takes into account typical schemes and models, scientific and empirical data as well as the requirements of efficiency and logics ${ }^{19}$. Supporting the opinion of S.S. Alkseyev, we also assume that judicial structures are models, typical schemes for making rights and duties, sanctions, warranties, other elements and grounds of legal regulation ${ }^{20}$.

Judicial structures can be simple, for instance, the structure of legal relations whose basic elements are the aggregate of rights and duties, and complex, for example, the structure of responsibility that consists of tort-nature legal relations and the ones representing the reaction of the state to the latter.

In our opinion, taking into account the peculiarities of nature and emergence of emotions, the judicial structures that help the legislator to regulate relations with regard to emotions are complex because they reflect the following: the catalyst, its effect and reaction of the relation party to it as well as its appraisal on the part of the state.

In the context of our research we should determine the elements of judicial structures that can be used to regulate emotion-related relations.

16 Р. фон Иеринг. Избранные труды в 2-х томах. Т. ІІ. Москва, 2006. С. 359.

17 Р. фон Иеринг. Избранные труды в 2-х томах. Т. ІІ. Москва, 2006. С. 367.

18 Алексеев С.В. Восхождение к праву. Поиски и решения. Москва: НОРМА, 2002. С. 241-263; Алексеев С.С. Собрание сочинений в 10 т. Москва, 2010. Т. 5. Линия права. Отдельные проблемы концепции. С. 219.

19 Алексеев С.С. Собрание сочинений в 10 т. Москва, 2010. Т. 5. Линия права. Отдельные проблемы концепции. С. 219.

20 Алексеев С.В. Восхождение к праву. Поиски и решения. Москва: НОРМА, 2002. C. 245 
This should enable us to define their distinct structure and understand their nature.

The analysis of practical use of law to regulate relations shows that emotion-related judicial structures are of complex nature. The constituent elements of the construction used by the legislator to regulate emotionrelated relations include the following: a) the emotion itself as an expression of human nature that must be taken into consideration for the purpose of legal regulation of social relations; b) the form of the outer expression of the emotion; c) its fixation mechanism; d) the appraisal on the part of the state. The first two elements are first-order elements because in their aggregate they reflect the emotion as a neurobiological activity of a person and its outer expression, and the other two elements are derivatives, i.e. the second-order elements that reflect a possible reaction of the state to the outer expression of the emotions.

When developing judicial structures to account emotions in relations, the legislation, in our opinion, should pay attention to the fact that such judicial structures must include the first-order elements in their aggregate. It can be explained by the fact that the appraisal of an emotion on the part of the state can take place only when the emotion has its outer expression and somehow influences the surrounding of the party, which expresses the emotion. It should also be noted that the fixation of the availability of the first-order elements must be of biological (medical) nature.

The second-order elements that reflect the reaction of the state to emotions in relations are those particles of judicial structures that enable to account emotions. The mechanism of emotion accounting can include both imperative elements, for example, have a clear list of emotions and emotional states of the party, and dispositional elements, i.e. include only a hint at the presence of an emotion as a neurobiological activity without being too exact.

Appraisal of emotion-driven actions as the last element of the judicial structure to be used to regulate emotion-related relations depends directly on the socio-cultural environment existing on the territory of the country. This is because every society develops in its individual way. At the same time in the process of its development it creates its own, intrinsic reactions to the expression of emotions by the society members. That is why in different societies the states can show different reactions to the same actions caused by emotions (for instance, murder caused by adultery in secular and religious states). 
The suggested four-element composition of judicial structures that can be used to regulate emotion-related relations seems to be the most effective, in our opinion, taking into account the nature of emotions. Furthermore, when dealing with tort situations, confirmed presence of the described elements of judicial structures in their unity can contribute to the establishment of justice in the society and renewal of public order.

Let us try to illustrate the provisions above. Since there exist numerous judicial structures, we should take only some of them that are vital for the existence of a person and her interaction both with other humans and the state. In particular, we consider the following judicial structures to be vital: the ones that can regulate relations connected with deprivation of life of one person by another, relations of people with their close relatives, relations connected with commercial or entrepreneurial activity.

Public order in almost any state is based on the assumption that emotions belong to the animal nature of human beings. Influenced by them, people act in a stupid and sometimes cruel way. When provoked, under the effect of anger or another emotion, people are sometimes able of committing a murder. Anger appears without any control, spontaneously, and a person cannot compare her behaviour with the provisions of the law. As a result, quite often the law takes such states into consideration and, when qualifying a situation under the influence of emotions, makes a decision using the judicial structure «in the heat of passion».

The judicial structure "in the heat of passion" is based on the emotion of anger. It (the emotion) can be expressed differently both in public (aggression in the time of mass actions) and private law (spontaneous actions in the form of juristic acts). These expressions can result, for instance, in committing of a murder in the former case or making of a will in the latter one.

Given the fact that the society is an aggregate of individuals and their groups, its functioning is accompanied with relations connected with the attitude of some members of the society to others. The most vivid example of such relations, which are directly connected with emotions, is family relations.

Sociological studies show ${ }^{21}$ that family connections are quite a strong base for the development of trustworthy relations that both emotionally and psychologically are based on the dependence of a child on her mother, agreement between spouses, large-heartedness of parents towards their

${ }^{21}$ Francisco Herreros. Ties that bind: Family relationships and social trust. Rationality and Society. 2015. July 16. 
child, flexibility for the elderly, awareness of the temper of close people, their peculiar habits and behavioural patterns. These connections are translated to habitual social norms when family members usually protect each other, come to the defense or even try to mislead others to protect their family. Since most people tend to act in the best interests of their near and dear ones, the law takes this situation into account in the most important areas for the society and applies the judicial structure of "social belonging".

The judicial structure of "social belonging" is based on the emotion of love, trust and intimacy. They can manifest themselves in a different way both in public (corruption) and private law (granting of uncompetitive advantages to close people). These expressions can result in the employment of a close relative in the former case and conclusion of a contract under more favorable terms in the latter one.

In economic relations, for instance, when the results of some work are exchanged, people enter into mutual relations and conduct certain legal juristic acts. In their essence these juristic acts possess the emotion of friendliness and trust. Unlike the former emotions described above, the emotion of trust is an emotional-psychological state that is characterized with certain duration in time and is typical (or even desired) for a human in society. Trust can be both expressed evenly as a short-term, weak emotion typical for mood, and also quite a long-lasting feeling that seems to absorb the personality and is typical for passion. Mood and passion are two types of trust that differ from each other in the degree of their influence upon the behaviour of a person. The first one, i.e. mood, can influence the behaviour for a short period of time and be reflected in activity, wellbeing and thinking. The second one, i.e. passion, can control the mind and behaviour of a person for quite a long time, stimulating her activity or, on the contrary, suppressing it. These emotions can be taken into account with the help of the judicial structure of "trust".

The judicial structure of "trust" is based on the emotion of friendliness and liking. This structure can be used to regulate relations both in public and private law. It can also be of both positive and negative nature.

\section{CONCLUSIONS}

Based on everything stated above, we can come to the following conclusions. Emotions are a neurobiological activity caused by certain factors that in its essence cannot be controlled by the person producing it. The presence of emotions leads to emotional experiences that can depend on the activity of a person, her health and temperament. 
The results of sociological research help get a better understanding and explain the influence of emotional states upon the establishment and prognosis of the development of social relations and, as such, they allow creating an effective mechanism to take these subjective factors into account with view of social regulation.

Since emotions are uncontrollable, they cannot be regulated by the law but, when regulating social relations, the law must take them into consideration. The use of judicial structures as models or typical schemes for the development of rights and duties, sanctions, warranties or other elements and grounds of judicial regulation can be called an instrument that enables rationalizing and foreseeing them. The judicial structures that can be used to regulate emotion-related relations must have a four-element composition, of which two elements (emotion, outer expression form) are first-order elements and the others (fixation mechanism, appraisal by the state) belong to the elements of the second order.

The results received can be applied both in law-creating (when preparing legislation instruments) and in law-administering (to qualify events) activity.

\section{SUMMARY}

The article deals with the interconnection between law and emotions. Using a multidisciplinary approach, the author studies emotions and emotional states as the elements of social interrelations. With the help of the latest achievements in psychology the author treats emotions as reflective biological manifestations of human being/behaviour and implements this notion in the field of judicial psychology, i.e. the author speaks about emotions as one of the main characteristics and qualities of human behaviour in general and in legal relations in particular.

Using the latest findings of sociology, the place and role of emotions in the creation/destruction of legal relations are discussed. Exact examples are used to show the influence of emotion presence/absence when relations are built/destroyed. The analysis that follows proves that society in general and its individual social groups in particular possess certain mechanisms to react to the emotions expressed by the members of relations in the form of social norms tried in social practice, which to a certain extent helps keep balance and stability both in these groups and in the society in general.

In the field of law emotions are specified, as a rule, as motives or guilt, in other words as explanations of certain behaviour patterns, as exceptions. At the same time neither law nor judicial practice acknowledges emotions as a required subjective factor that is to be taken into consideration in 
lawmaking, law-establishing or law-using activity. In this article the author offers a mechanism to consider emotions in law.

\section{REFERENCES}

1. Bergman, Blix S., Wettergren, A. A Sociological Perspective on Emotions in the Judiciary. Emotion Review. Vol. 8, Iss. 1. 2016. DOI: $10.1177 / 1754073915601226$.

2. Bericat, E. (2015) The sociology of emotions: Four decades of progress. Current Sociology. № 64 (3). June 2015. DOI: $10.1177 / 0011392115588355$.

3. Edelman, G.M., Tononi, G. A Universe of Consciousness : How Matter Becomes Imagination. New York : Basic Books. 2000. 274 pp.

4. Francisco Herreros. Ties that bind: Family relationships and social trust. Rationality and Society. 2015. July 16. DOI: 10.1177/1043463115593122.

5. Holland, J. Emotions and Research. International Journal of Social Research Methodology. 2007. Vol. 10. Iss. 3. P. 195-209. DOI: 10.1080/13645570701541894.

6. Izard, Carroll E. Emotion Theory and Research: Highlights, Unanswered Questions, and Emerging Issues. Annual Review of Psychology. Vol. 60. P. 1-25. DOI: 10.1146/annurev.psych.60.110707.163539.

7. Langer, S.K. (1967/1982) Mind: An Essay on Human Feeling. Baltimore, MD : Johns Hopkins University Press, Vol. 1. P. 101.

8. Louwanda Evans, Joe R. Feagin (2015) The Costs of Policing Violence: Foregrounding Cognitive and Emotional Labor. Critical Sociology. DOI: $10.1177 / 0896920515589727$.

9. Marker, B. Consciousness without a cerebral cortex: a challenge for neuroscience and medicine. Behavioral and Brain Sciences. 2007. Vol. 30, Iss. 1. P. 63-81. DOI: 10.1017/S0140525X07000891.

10. Posner, R.A. Frontiers of Legal Theory. Harvard : Harvard University Press. 2004. 464 p.

11. Posner, R.A. Frontiers of Legal Theory. Published by arrangement with Harvard University Press. 225 p.

12. Symposium on Law, Psychology, and the Emotions. Chicago-Kent Law Review. 2000. Vol. 741.

13. The Passions of Law / ed. S.F. Bandes. New York : University Press, New York and London, 1999. 236 p.

14. Weenink, D. (2014) Frenzied attacks. A micro-sociological analysis of the emotional dynamics of extreme youth violence. Vol. 65, Iss. 3. P. 411-433. DOI: 10.1111/1468-4446.12088.

15. Алексеев С.В. Восхождение к праву. Поиски и решения. Москва : HOPMA, 2002. C. 245 
16. Алексеев С.С. Собрание сочинений в 10 т. Москва : 2010. Т. 5. Линия права. Отдельные проблемы концепции. С. 219.

17. Велика українська юридична енциклопедія : у 20 т. Т. 2. Харків : Право, 2017. С. 255-258.

18. Вест Р. Правові емоції. Філософія права $i$ загальна теорія права. 2015. № 1-2. URL: https://pravoua.com.ua/ua/store/philosophy/ phil-law_1-2_15/.

19. Иеринг Р. Избранные труды в 2-х томах. Санкт-Петербург : Юридический центр пресс, 2006. Т. 2. 547 с.

20. Крюкова Е.А. Управление эмоциями как фактор эффективного менеджмента. Российское предпринимательство. 2015. Т. 16. № 12. C. $1937-1948$. DOI: $10.18334 / \mathrm{rp} .16 .12 .412$

21. Муазі Д. Геополітика емоцій. Як культара страху, приниження та надії змінюють світ. Київ : Брайт Стар Паблішинг, 2018. 184 с.

22. Познер Р.А. Утилитаризм, экономика и теория права. Концепция права. Экономический анализ права. C. 46-88. URL: https://cyberleninka. $\mathrm{ru} /$ article/n/utilitarizm-ekonomika-i-teoriya-prava/viewer.

23. Таллер Р. Поведінкова економіка / перекл. 3 англ. С. Крикуненко. Київ : Наш формат, 2018. 464 с.

24. Эльстер Ю. Объяснение социального поведения: еще раз об основах социальных наук. Москва : Высшая школа экономики, 2011. 472 с.

\section{Information about author:}

Ustymenko O. A., Ph.D. in Law, Head of the Department of Civil Law V. N. Karazin Kharkiv National University 4, square Svobody, Kharkiv, Ukraine

DOI https://doi.org/10.30525/978-9934-588-43-3/2.26 